\title{
Znaczenie zasady ostrożności we wspótczesnej rachunkowości
}

\author{
The significance of the prudence principle in contemporary accounting
}

\section{Wstęp}

System rachunkowości ewoluuje. Rosnące potrzeby informacyjne użytkowników sprawozdania finansowego, wprowadzenie wyceny według wartości godziwej i związane z tym dopuszczenie przeszacowań, skłaniają do zastanowienia się nad dalszą zasadnością stosowania zasady ostrożności. Biorąc pod uwagę rosnące znaczenie wartości godziwej jako parametru wyceny, nasuwa się pytanie: czy zasada ostrożności straciła rację bytu, a jej stosowanie należy uznać za relikt przeszłości? Czy pozbawienie jej rangi nadrzędnej zasady rachunkowości w Założeniach Koncepcyjnych MSSF i uznanie jedynie jako cechy wspierającej neutralność sprawozdań finansowych jest równoznaczne z jej marginalizacją?

Celem tego opracowania jest przedstawienie znaczenia zasady ostrożności we współczesnej rachunkowości. W tym celu omówiono jej istotę oraz uregulowanie w prawodawstwie krajowym i międzynarodowym. Kolejno przedstawione zostały argumenty za i przeciw stosowaniu zasady ostrożności. W końcowej części podjęto rozważania nad współczesnym znaczeniem tej reguły w obliczu stosowania wartości godziwej i wejścia w życie MSSF 15.

W opracowaniu zastosowano metody przeglądu oraz analizy opisowej i porównawczej treści zawartych w dostępnej literaturze przedmiotu z zakresu rachunkowości. Wykorzystano również normy prawne, gdyż litera prawa w sposób bezpośredni reguluje badane zagadnienie. 


\section{Istota zasady ostrożności}

Zasada ostrożności jest jedną z najstarszych nadrzędnych zasad rachunkowości. Jej prekursorem był Jacques Savary, który pełnił funkcję urzędnika państwowego i eksperta w dziedzinie handlu na dworze króla Ludwika XIV. Jednocześnie był autorem zapisów dotyczących rachunkowości we francuskim Kodeksie handlowym z $1673 \mathrm{r}$. Opracowanie to stanowi pierwsze, prawne uregulowanie zasady ostrożności. W podręczniku pt. Le Parfait Négociant Savary wskazuje, że „przy wycenie trzeba się strzec, aby towarów nie oceniać wyżej, niż są warte, bo to znaczyłoby, że czyni się bogatym na papierze. Należy raczej je tak oceniać, aby przy sprzedaży w przyszłości wydobyć zysk w inwentarzu roku następnego" (Hońko, 2010, s. 59). Tym samym Savary sformułował pierwotną definicję zasady ostrożności.

Współcześnie istota zasady ostrożności została określona w regulacjach krajowych i międzynarodowych. Szczegółową charakterystykę, z wyszczególnieniem określających ją artykułów, zawarto w tabeli 1.

Wprowadzenie zasady ostrożności do Ustawy o rachunkowości ma na celu ograniczenie swobody w wycenie składników majątkowych. Jej przestrzeganie prowadzi do właściwego i rzetelnego odzwierciedlenia niewątpliwych w sensie memoriałowym przychodów (Babuśka, 2014, s. 41), poniesionych kosztów oraz uwzględnienia związanego z nimi ryzyka gospodarczego (Helin, 2017, s. 203).

Na gruncie prawa międzynarodowego zasada ostrożności pojawia się w różnych aktach prawnych. W Preambule Dyrektywy Parlamentu Europejskiego i Rady wymienia się ją, obok zasady kontynuowania działania i memoriału, jako gwarancję porównywalności i równoważności informacji ujawnianych w sprawozdaniach (Parlament Europejski, 2013, pkt. 16). Dodatkowo przy dokonywaniu szacunków pozycji sprawozdań finansowych, których nie można precyzyjnie wycenić, należy kierować się ostrożnością (Parlament Europejski, 2013, pkt. 22).

W Założeniach Koncepcyjnych Sprawozdawczości Finansowej zasada ostrożności pojawiała się, a następnie znikała kilkukrotnie. Po raz pierwszy uwzględniono ją w roku 1989 jako cechę objaśniającą wiarygodność. W 2010 r. Rada Międzynarodowych Standardów Rachunkowości wycofała ją, motywując to jej domniemaną sprzecznością z cechą neutralności, co wywołało falę krytyki. Jak pisze Magdalena Głębocka: „usunięcie zasady ostrożności z Założeń koncepcyjnych MSSF nie oznacza, że zasada ta przestała obowiązywać a jednostki zostały zwolnione z konieczności zachowania rozsądku w szacunkach wartości składników majątku" (Głębocka, 2016, s. 89-90). Dodatkowo Philippe Danjou wskazuje, że pomimo usunięcia zasady ostrożności z Założeń Koncepcyjnych ma ona istotne znaczenie dla niektórych MSSF (np. MSR 36 i 39 - Danjou, 2013). 


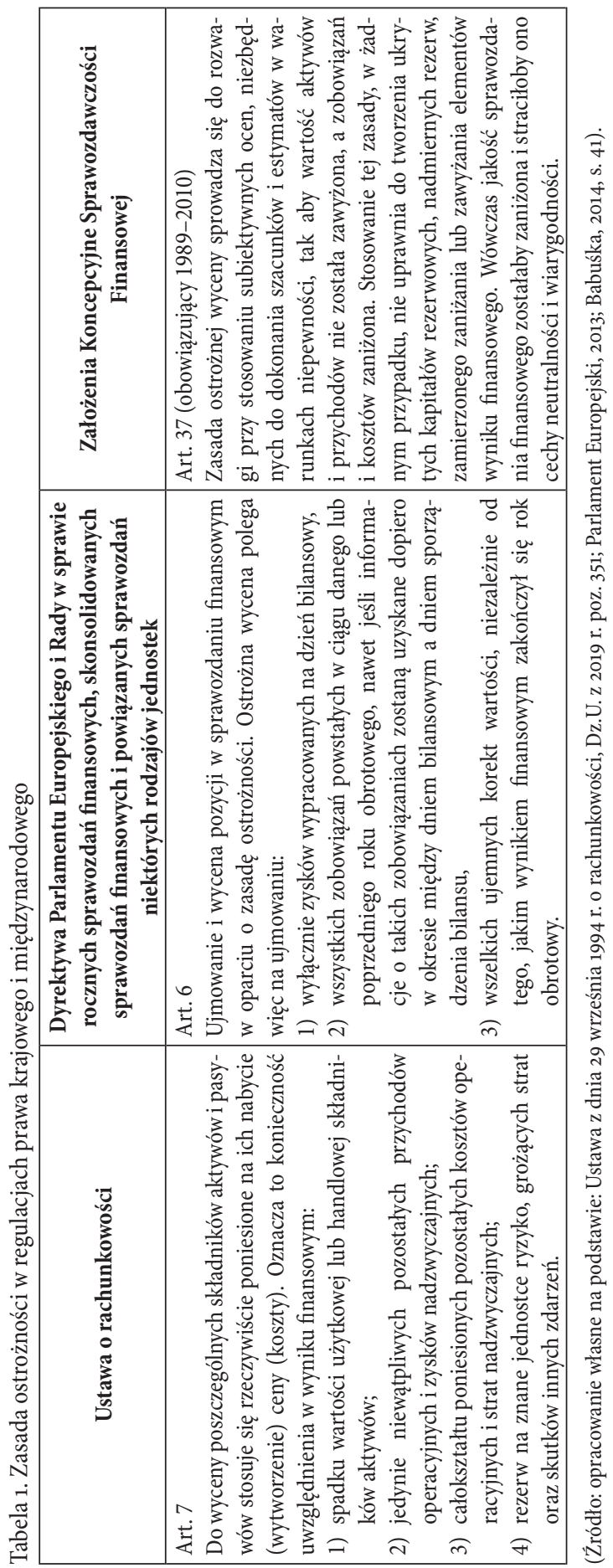


Ostatecznie, w marcu 2018 roku, zasada ostrożności powróciła do Założeń Koncepcyjnych jako wykazanie rozwagi przy stosowaniu ocen w warunkach niepewności. Takie pojmowanie ostrożności ma wspierać neutralność sprawozdań finansowych i nie prowadzić do zawyżania lub zaniżania wartości aktywów, pasywów, kosztów i przychodów (Conceptual Framework for Financial Reporting, 2018, s. 6). Oznacza to, że RMSR w Założeniach Koncepcyjnych traktuje ostrożność jedynie jako cechę wspierającą neutralność i wiarygodność sprawozdań finansowych, a nie jak nadrzędną zasadę rachunkowości, tak jak dzieje się to w przypadku regulacji krajowych. Pomimo wprowadzenia tych uściśleń w literaturze przedmiotu można spotkać poglądy przemawiające za przywróceniem zasadzie ostrożności rangi jednej z nadrzędnych reguł rachunkowości (Zob. Oreshkova, 2017).

Istotę zasady ostrożności w sposób syntetyczny najlepiej oddają stwierdzenia: „nie wyżej niż cena rynkowa” czy „lepszy zysk mniejszy niż przesadzony” (Micherda, 2001, s. 73). Jednakże dotyczą one jedynie kwestii związanych z wyceną aktywów i pasywów oraz ustalaniem kosztów i przychodów. Natomiast zasady ostrożności nie można utożsamiać tylko z ostrożną wyceną, gdyż ta pierwsza jest pojęciem szerszym. Obecnie należy ją rozumieć jako filozofię prezentacji danych w sprawozdaniu finansowym (Helin, 2017, s. 203), a więc „rozwagę w ocenie skutków finansowych przeszłych i przyszłych zdarzeń z uwzględnieniem ryzyka towarzyszącego działalności jednostki” (Głębocka, 2016, s. 88).

\section{Argumenty za i przeciw stosowaniu zasady ostrożności}

W literaturze przedmiotu prezentowane są liczne argumenty przemawiające zarówno za, jak i przeciw stosowaniu zasady ostrożności. Dotyczą one na ogół jej klasycznej interpretacji.

Zwolennicy zasady ostrożności podnoszą, że jej właściwe stosowanie zapewnia wiarygodność informacji finansowych. Wymusza ona bowiem realną wycenę majątku oraz wykazanie rzeczywiście wygospodarowanych wyników, a zarazem uniemożliwia powstanie „inflacyjnych” zysków i dekapitalizację majątku podmiotu (Gmytrasiewicz \& Karmańska, 2006, s. 24). W ten sposób dostarcza użytkownikom sprawozdań realnych, przystających do rzeczywistości informacji o jednostce gospodarczej.

Dodatkowo zasada ostrożności ma powstrzymać zarządzających przed tworzeniem nadmiernie optymistycznych szacunków czy wyolbrzymiania dokonań. 
Sytuacja, w której znaczące pozycje sprawozdania finansowego oparte są na oszacowaniach, daje sposobność do powstania w nim nieprawidłowości (Hołda, 2005, s. 297). Tym samym zasada ostrożności chroni użytkowników sprawozdania finansowego, gdyż przeszacowanie wartości jest dla nich bardziej niebezpieczne niż jej niedoszacowanie (Wędzki, 2014, s. 101-102).

Przyjmuje się, że tradycyjnej zasadzie ostrożności towarzyszy pesymizm, przejawiający się zbytnią przezornością przy ujmowaniu zjawisk. Postawa ta często poddawana jest krytyce, gdyż w jej wyniku może nastąpić niedoszacowanie wartości aktywów i przychodów lub przeszacowanie zobowiązań i kosztów. Takie podejście narusza neutralność i wiarygodność danych zawartych w sprawozdaniu finansowym. W konsekwencji może wprowadzać w błąd jego poszczególnych użytkowników. Przykładowo inwestorzy, którzy dysponując przekłamanym obrazem sytuacji finansowej jednostki, mogą np. sprzedać swoje akcje lub udziały po zaniżonej cenie (Hasik, 2019, s. 68).

W tym kontekście należałoby zgodzić się ze stanowiskiem Edyty Łazarowicz, że celowe zaniżanie lub zawyżanie danych „nie jest istotą stosowania (...) zasady [ostrożności - przyp. autora], lecz problemem etyki osób odpowiedzialnych za sporządzanie sprawozdań finansowych" (Łazarowicz, 2015, s. 187). Prawidłowe stosowanie zasady ostrożności nie zniekształca wartości aktywów, pasywów, kosztów i przychodów, a więc nie prowadzi do naruszenia wiarygodności sprawozdań finansowych. Można więc przyjąć stanowisko, że obecny w zasadzie ostrożności subiektywizm zależy od charakteru osoby oceniającej zagrożenia (optymista/ pesymista), a także od przyjętej przez kierownictwo polityki w zakresie ujawnień wyniku finansowego (Krzywda, 2007, s. 25-26).

Krytycy zasady ostrożności podnoszą również pogląd, że zbytnia zachowawczość w wycenie może przyczynić się do zawyżania wyników w następnych okresach (Hasik, 2019, s. 68). Dodatkowo brak jednolitych wytycznych w kwestii jej stosowania ogranicza porównywalność sprawozdań finansowych (Hendriksen \& van Breda, 2002, s. 168).

Warto także podkreślić, że zasada ostrożności, oparta na koszcie historycznym, negowana jest za brak charakteru prospektywnego, który przypisuje się wartości godziwej. Jednakże przytoczony art. 7 Ustawy o rachunkowości wyraźnie wskazuje, że w wyniku finansowym należy uwzględnić wszystkie czynniki związane z niepewnością otoczenia, w którym funkcjonuje jednostka. Wiarygodne przedstawienie sytuacji majątkowo-finansowej podmiotu wymaga uwzględnienia wszystkich przychodów i kosztów oraz przyszłych przewidywanych strat. Rodzi również konieczność weryfikacji stanu rzeczywiście posiadanego majątku oraz przeprowadzenie korekt, gdy wartość użytkowa lub handlowa 
aktywów spadła, a zobowiązań - wzrosła. Dokonując weryfikacji założonego poziomu oczekiwanych korzyści ekonomicznych, należy zawsze kierować się rozwagą, bez względu na fakt, czy stosuje się historyczne, bieżące czy przyszłe parametry wyceny (Hońko, 2010, s. 53). Zasada ostrożności łączy więc w sobie wycenę retro- i prospektywną elementów wyniku finansowego. Nie ogranicza się wyłącznie do rejestrowania transakcji ex post, ale poprzez uznanie niezrealizowanych jeszcze strat wprowadza ex ante do systemu rachunkowości (Bareja, 2018, s. 29-30) (por. rysunek 1).

Rysunek 1. Zależność zasady ostrożności od czasu oddziaływania

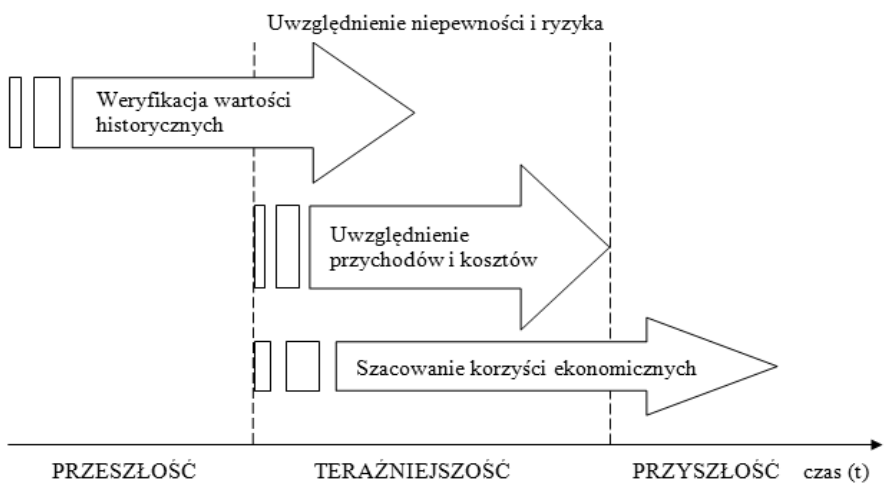

(Źródło: Hońko, 2008, s. 54).

W tym kontekście należy również wspomnieć, że zasada ostrożności określana jest jako „zasada niekonsekwencji”. Skrzywan (1971, s. 201) pisał, że zasada ostrożności polega na „antycypowaniu strat wynikających z obniżki cen składników majątkowych, lecz nieuwzględnianiu zysków niezrealizowanych, powstałych na skutek zwyżki cen". Tym samym akceptuje niezrealizowane straty, lecz nie dopuszcza niezrealizowanych zysków.

\section{Współczesne znaczenie zasady ostrożności}

Wprowadzenie wyceny według wartości godziwej spowodowało, że tradycyjna zasada ostrożności, oparta na koszcie historycznym, zaczęła stopniowo tracić na znaczeniu. Wynika to z dopuszczenia przeszacowań, które dają możliwość zwiększenia wartości aktywów i zmniejszenia zobowiązań. Wartość godziwa odnosi się do kwoty hipotetycznej transakcji sprzedaży, przez co pozwala ująć przychody wątpliwe i niepewne, które faktycznie nie zostały zrealizowane. 
W praktyce, dla zachowania zasady ostrożności, wycenę w wartości godziwej powinno stosować się, jeżeli wartość rynkowa aktywów podlegających wycenie spadła, a więcjedynie w przypadku korekt in minus. Wartość godziwa nie powinna stanowić podstawy wyceny, gdy jest wyższa od kosztu historycznego. Wówczas dokonanie korekt in plus jest równoznaczne z uwzględnieniem niezrealizowanego przychodu (Rówińska \& Zadora, 2012, s. 170).

Warto zaznaczyć, że leżące u podstaw wartości godziwej dokonanie wyceny na podstawie danych rynkowych może rodzić trudności, gdyż nie wszystkie rynki są jednakowo rozwinięte, a dla wielu składników aktywny rynek nie istnieje (Błażyńska, 2015, s. 82). Wówczas konieczne jest przejście niżej w hierarchii wartości godziwej, co zwiększa zakres decyzji indywidualnych podejmowanych przez wyceniającego. W efekcie wycena uzależniona jest od subiektywnie przyjętych założeń (Szczepankiewicz \& Janowicz, 2015, s. 92).

Wycena w myśl wartości godziwej stosowana jest przede wszystkim przez podmioty, które sporządzają swoje sprawozdania finansowe według MSSF. Istnieje szereg standardów, w których kluczowe znaczenie ma zasada ostrożności (np. MSR 36, MSR 37, MSSF 5). Jednakże, w kontekście ostatnio prowadzonych prac legislacyjnych na uwagę zasługuje Standard 15 „Przychody z umów z klientami”, który wszedł w życie w 2018 r. Dotyczy on przychodów - jednego z głównych mierników dokonań przedsiębiorstwa. Kategoria ta bezpośrednio przekłada się na osiągnięty wynik finansowy, a więc znajduje się w centrum uwagi poszczególnych użytkowników sprawozdania finansowego. Nie ulega więc wątpliwości, że przy ujmowaniu przychodów należy zachować najwyższą ostrożność.

W Standardzie 15 obowiązuje podejście bilansowe do przychodów, tzn. traktuje się je jako zwiększenie aktywów lub zmniejszenie zobowiązań (Walińska \& Jurewicz, 2015, s. 217-218). Dla prawidłowego ujęcia przychodów należy wykonać pięć kroków (rysunek 2).

Rysunek 2. Etapy ustalania przychodu według MSSF 15

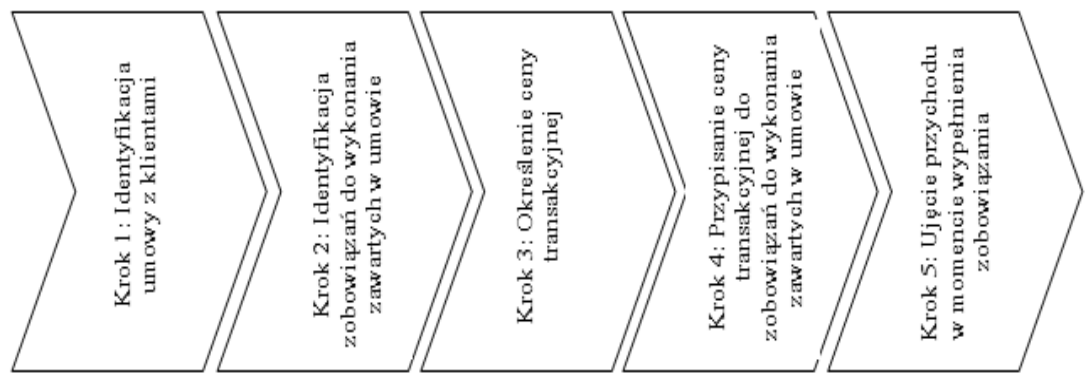

(Źródło: opracowanie na podstawie: MSSF, 2014, s. 4). 
Pierwszy krok w analizie ujmowania przychodów stanowi identyfikacja umowy. Zgodnie z zapisami Standardu kontrakt zostaje zawarty pomiędzy dwiema lub więcej stronami. W wyniku tego porozumienia powstają egzekwowalne prawa i obowiązki stron. Kontrakt określa warunki płatności za przekazane dobra lub usługi oraz posiada treść ekonomiczną. Dodatkowo zakłada istnienie prawdopodobieństwa otrzymania należnego wynagrodzenia w zamian za wykonanie umownych zobowiązań.

Następnie jednostka musi wskazać poszczególne zobowiązania do wykonania w ramach zawartej umowy, a więc określić jakie dobra lub usługi jest zobligowana dostarczyć lub wykonać na rzecz kontrahenta (krok drugi) (Wydawnictwo Podatkowe Gofin, 2018, s. 24-27).

Z punktu widzenia zasady ostrożności najbardziej istotny wydaje się etap trzeci, który dotyczy szacowania kwoty przychodu. Cenę transakcyjną stanowi kwota wynagrodzenia, którą jednostka spodziewa się otrzymać w zamian za przekazanie przyrzeczonych w kontrakcie dóbr lub usług. Przy jej ustalaniu należy wziąć pod uwagę takie elementy jak zmienność wynagrodzenia (rabaty, upusty cenowe, premie itp.) czy wartość pieniądza w czasie (MSSF, 2014, s. 6). MSSF 15 wskazuje dwie metody stosowane do określenia wartości przychodu:

1. Metoda wartości oczekiwanej, będąca sumą iloczynów możliwych do uzyskania kwot wynagrodzenia z przypisanymi im prawdopodobieństwami wystąpienia,

2. Metoda wartości najbardziej prawdopodobnej, zgodnie z którą wysokość przychodu jest równa jednostkowej, najbardziej prawdopodobnej do uzyskania kwocie spośród wszystkich możliwych wynagrodzeń.

Przy wyborze optymalnej metody jednostka uwzględnia posiadane historyczne i bieżące informacje, prognozy, wiedzę, doświadczenie i stosowane praktyki handlowe) (Wydawnictwo Podatkowe Gofin, 2018, s. 48-49). Aby ujęcie przychodów we właściwej wysokości i w odpowiednim okresie było poprawne, musi opierać się na profesjonalnych szacunkach. Nie ulega więc wątpliwości, że osoby je sporządzające powinny przede wszystkim kierować się zasadą ostrożności.

Jeżeli jednostka w ramach umowy realizuje różne świadczenia, wówczas powinna dokonać przypisania ceny transakcyjnej do poszczególnych zobowiązań (krok czwarty). W ostatnim etapie następuje ujęcie przychodu w momencie spełnienia umownych zobowiązań do wykonania, a więc z chwilą przeniesienia na kontrahenta kontroli nad towarem lub usługą (MSSF, 2014, s. 8). 


\section{Podsumowanie}

Obecnie wymaga się, aby rachunkowość była zarówno systemem ewidencyjno-sprawozdawczym, jak i analityczno-planistycznym. Wprowadzenie wyceny według wartości godziwej i dopuszczenie związanych z tym przeszacowań spowodowało, że tradycyjna zasada ostrożności, oparta na koszcie historycznym, stopniowo traci na znaczeniu. W tym względzie, nie bez znaczenia były prace RMSR nad Założeniami Koncepcyjnymi. W ich wyniku zasada ostrożności przestała być jedną z nadrzędnych zasad rachunkowości, a stała się jedynie cechą wspierającą neutralność i wiarygodność sprawozdań finansowych jednostek stosujących MSSF. Jednakże wspomniane przekwalifikowanie znaczenia zasady ostrożności nie jest równoznaczne z brakiem jej stosowania. Przeciwnie, istnieje szereg standardów, w których zasada ostrożności ma kluczowe znaczenie. Dodatkowo, stosowanie wartości godziwej jako parametru wyceny oraz przyjęcie Standardu 15, które w pewnym stopniu opierają się na szacunkach, potwierdzają, że przy ich dokonywaniu należy kierować się ostrożnością. W regulacjach krajowych zasada ostrożności nadal traktowana jest jako jedna z nadrzędnych reguł rachunkowości.

Współcześnie odchodzi się „od definicji ostrożności jako zasady sensu stricto do nastawienia ostrożnościowego, niedefiniowanego wprost w przepisach. Ostrożność oznaczać będzie ostrożne podchodzenie do danych szacunkowych, na które wpływają ryzyko i niepewność" (Giedroyć, 2007, s. 64). Zdaniem autora prawidłowe stosowanie zasady ostrożności gwarantuje poprawne ujęcie danych finansowych. W tym względzie nieistotne jest, czy w przepisach prawa ujmuje się ją jako cechę, czy jako zasadę. Ważne, aby przy sporządzaniu sprawozdań finansowych zawsze kierować się rozwagą, bez względu na fakt, czy stosuje się historyczne, bieżące czy przyszłe parametry wyceny. W przeciwnym razie wiarygodność płynących z nich informacji może być wątpliwa. Dotyczy to wszystkich podmiotów stosujących zarówno regulacje krajowe, jak i międzynarodowe.

\section{Bibliografia}

\section{Akty prawne}

Ustawa z dnia 29 września 1994 r. o rachunkowości, Dz.U. z 2019 r. poz. 351.

Parlament Europejski (2013). Dyrektywa Parlamentu Europejskiego i Rady 2013/34/UE $z 26$ czerwca $2013 r$ r. $w$ sprawie rocznych sprawozdań finansowych, skonsolidowanych sprawozdan finansowych i powiazanych sprawozdań niektórych rodza- 
jów jednostek. Dz.U. 2013, nr 182. Pozyskano z https://www.pibr.org.pl/assets/ file/1039,dyrektywa-2013-34-UE-PL.pdf (dostęp: 13.11.2019).

\section{Literatura}

Babuśka, E. W. (2014). Teoria rachunkowości w tworzeniu i rozwijaniu zasad rachunkowości. W: B. Micherda (red.), Teoria rachunkowości a jej współczesne regulacje (ss. 27-48). Warszawa, Polska: Wydawnictwo Difin.

Bareja, K. (2018). Ostrożność w rachunkowości - zasada czy cecha jakościowa? Prace Naukowe Uniwersytetu Ekonomicznego we Wrocławiu, 503, 26-36.

MSSF (2014). Naprzeciw standardom. Pozyskano z https://www2.deloitte.com/content/dam/Deloitte/pl/Documents/Newsletters/Biuletyn-MSSF/pl_Biuletyn_ MSSF_2014_03.pdf (dostęp: 12.11.2019).

Błażyńska, J. (2015). Wartość godziwa jako podstawa wyceny w sprawozdaniu finansowym. Studia i Prace Kolegium Zarzadzania i Finansów Szkoły Głównej Handlowej, $147,73-85$.

Conceptual Framework for Financial Reporting (2018). Pozyskano z https://www.ifrs. org/-/media/project/conceptual-framework/fact-sheet-project-summary-and-feedback-statement/conceptual-framework-project-summary.pdf (dostęp: 10.11.2019).

Danjou, P. (2013). An Update on International Financial Reporting Standards (IFRSs). Pozyskano z http://www.actuaries.org/CTTEES_PENSEB/Documents/Hague_ Item4.8.2_MisunderstandingsAboutIFRSsFeb2013.pdf (dostęp: 08.11.2019).

Giedroyć, M. (2007). Zasada ostrożności - artykuł dyskusyjny. Forum Rachunkowości, $1,62-68$.

Głębocka, M. (2016). Współczesny wymiar zasady ostrożności. Finanse, Rynki Finansowe, Ubezpieczenia, 8o(2), 86-95.

Gmytrasiewicz, M., \& Karmańska, A. (2006). Rachunkowość finansowa. Warszawa, Polska: Wydawnictwo Difin.

Hasik, W. (2019). Koncepcje i elementy (kategorie) sprawozdawczości finansowej według MSSF. W: B. Nita \& W. Hasik (red.), Sprawozdanie finansowe według MSSF (ss. 60-79). Warszawa, Polska: Wydawnictwo Wolters Kluwer Polska.

Helin, A. (2017). Ustawa o rachunkowości. Komentarz. Warszawa, Polska: Wydawnictwo C. H. Beck.

Hendriksen, E. A., \& van Breda, M. F. (2002). Teoria rachunkowości. Warszawa, Polska: Wydawnictwo Naukowe PWN.

Hołda, A. (2005). Atestacja informacji ekonomicznych z system rachunkowości. W: M. Dobija (red.), Teoria rachunkowości w zarysie (ss. 272-303). Kraków, Polska: Wydawnictwo Akademii Ekonomicznej w Krakowie. 
Hońko, S. (2008). Koncepcja ostrożnej wyceny w rachunkowości. Szczecin, Polska: Wydawnictwo Naukowe Uniwersytetu Szczecińskiego.

Hońko, S. (2010). Koncepcja ostrożnej wyceny w rachunkowości. Studia i Prace Wydziału Nauk Ekonomicznych i Zarządzania Uniwersytetu Szczecińskiego, 20, 55-68.

Krzywda, D. (2007). Nadrzędne zasady rachunkowości a ich adekwatność do regulacji określających poprawność sprawozdań finansowych. Zeszyty Naukowe Akademii Ekonomicznej w Krakowie, 750, 21-34.

Łazarowicz, E. (2015). Znaczenie i przyszłość zasady ostrożności. Prace Naukowe Uniwersytetu Ekonomicznego we Wrocławiu, 390, 183-190.

Micherda, B. (2001). Analityczna funkcja rachunkowości. Kraków, Polska: Wydawnictwo Akademii Ekonomicznej w Krakowie.

Oreshkova, H. (2017). The debate on prudence in accounting. Innovations in Science and Education, 5, 343-36o. Pozyskano z https://ojs.journals.cz/index.php/CBUIC/ article/view/949/pdf (dostęp: 15.12.2019).

Rówińska, M., \& Zadora, K. (2012). Rachunkowość w wartości godziwej a zasady rachunkowości. W: H. Buk \& A. Kostur (red.), Za i przeciw wartości godziwej w rachunkowości. Teoretyczne aspekty wartości godziwej (ss. 165-172). Katowice, Polska: Wydawnictwo Uniwersytetu Ekonomicznego w Katowicach.

Skrzywan, S. (1971). Teoretyczne podstawy rachunkowości. Warszawa, Polska: PWE.

Szczepankiewicz, E. I., \& Janowicz, M. (2015). Dylematy wykorzystania wartości godziwej - teoria i praktyka. Studia i Prace Kolegium Zarządzania i Finansów Szkoły Głównej Handlowej, 147, 87-107.

Walińska, E., \& Jurewicz, A. (2015). Koncepcje ujmowania przychodów w systemie rachunkowości - stan obecny i proponowane zmiany. Finanse, Rynki Finansowe, Ubezpieczenia, 77, 211-223.

Wędzki, D. (2014). Podstawy teorii sprawozdania finansowego. W: M. Dobija (red.), Teoria rachunkowości. Podstawa nauk ekonomicznych (ss. 70-104). Kraków, Polska: Wydawnictwo Uniwersytetu Ekonomicznego w Krakowie.

Wydawnictwo Podatkowe Gofin (2018). Przychody ze sprzedaży według Ustawy o rachunkowości i MSR. Zeszyty Metodyczne Rachunkowości. Dodatek, 13, 24-27, 48-49.

\section{Streszczenie}

W artykule przedstawiono znaczenie zasady ostrożności w rachunkowości. W tym celu omówiono jej istotę i uregulowanie w prawodawstwie krajowym oraz międzynarodowym. Kolejno przedstawione zostały argumenty za i przeciw stosowaniu zasady ostrożności. W końcowej części podjęto rozważania nad współczesnym znaczeniem tej reguły w obliczu stosowania wartości godziwej i wejścia w życie MSSF 15. Przegląd oraz analiza opisowa i porównawcza literatury przedmiotu oraz aktów prawnych pozwalają 
stwierdzić, że pojmowanie tej zasady w ostatnim czasie uległo zmianie. Związane jest to $\mathrm{z}$ rosnącym znaczeniem wartości godziwej jako parametru wyceny, dopuszczeniem przeszacowań oraz zmianami w Założeniach Koncepcyjnych MSSF. Obecnie odchodzi się od klasycznego ujęcia zasady ostrożności na rzecz podejścia ostrożnościowego, w którym zasada ostrożności interpretowana jest jako zachowanie rozwagi przy dokonywaniu szacunków.

SŁowA KLUCzowE: zasada ostrożności, Ustawa o rachunkowości, Założenia Koncepcyjne MSSF, MSSF 15

\section{Summary}

The article presents the significance of the prudence principle in accounting. The purpose of this article is to present the principle and regulation in national and international legislation, arguments for and against the prudence principle. The final part discusses the contemporary significance of the prudence principle in the face of applying fair value and the entry into force of IFRS 15 . Review, descriptive and comparative analysis of the literature on the subject and legal acts, allows to state that the understanding of this principle has changed recently. This is due to the growing importance of fair value as a measurement parameter, the admission of revaluations and changes in IFRS Conceptual Framework. Currently, the classic approach to the prudence principle is being moved in favour of the precautionary approach, in which the prudence principle is interpreted as being prudent when making estimates.

Keywords: the prudence principle, Accounting Act, Conceptual Framework for Financial Reporting, IFRS 15

\section{Nota o autorze}

Mgr Anna Mizak - Katolicki Uniwersytet Lubelski Jana Pawła II, Wydział Nauk Społecznych, Instytut Ekonomii i Finansów, Katedra Rachunkowości; główne dziedziny działalności naukowej: organizacja i prawne uregulowanie systemu rachunkowości jednostek gospodarczych; e-mail: anna.mizak@kul.pl, ORCID: 0000-0003-1250-0195. 